\title{
MENJADI JUTAWAN DENGAN MEMBUAT BUSUR PANAH LOW BUDGET HIGH QUALITY
}

\author{
Suandi Selian ${ }^{1 *}$, Dodi Irwansyah ${ }^{1}$ \\ ${ }^{1}$ Jurusan Pendidikan Olahraga, Fakultas Keguruan dan Ilmu Pendidikan, Universitas Samudra, Langsa, Indonesia \\ *Penulis Korespondensi: soeandieselly@ymail.com
}

\begin{abstract}
Abstrak
Busur Panah PVC adalah busur panah yang memiliki beberapa keunggulan dibandingkan busur panah lainnya yaitu ekonomis dan katahan di pakai sampai 1000 hero di lepaskan dari busur tersebut. Pipa PVC merupakan perlengkapan yang sering digunakan untuk mengalirkan air dari satu tempat ke tempat yang lain. Pipa PVC mempunyai kekuatan yang baik bila dibandingkan dengan pipa lainnya. Busur Panah PVC adalah busur panah yang dibuat dari pipa PVC. Prosesnya pembuatan busur panah dilakukan dengan teknik yang sangat sederhana dan semuanya dilakukan pada suhu yang relatif rendah. Pipa PVC yang dipotong dan disesuaikan dengan ukuran yang diinginkan lalu dipres ujungnya. Pengepresan ini diproses lebih lanjut dengan cara menggunakan alat pres pipa dengan menggunakan tenaga manusia, lalu didiamkan selama 25 Menit sampai terbentuk busur panah, lalu pipa yang sudah di pres dan mebentuk busur tadi di cat dengan menggunakan cat minyak sesuai warna yang di inginkan. Hasilnya dari pengecatan ini didiamkan sampai cat mengering dan selanjutnya dilakukan pelapisan pegangan busur dengan menggunakan benang nilon sehingga saat telapak tangan memegang busur tidak licin sehingga saat menarik tali busur tangan tidak terlepas dari busur panah tersebut. Busur panah PVC ini memiliki nilai ekonomis tinggi karena dapat digunakan untuk kalangan anak - anak , remaja sampai dewasa sehingga tidak harus membeli busur panah yang harganya jauh lebih mahal dibandingkan busur panah yang terbuat dari pipa PVC tersebut sehingga busur panah PVC ini dapat dijadikan peluang usaha bagi masyarakat setempat untuk meningkatkan perekonomian mereka.
\end{abstract}

Kata Kunci: Menjadi Jutawan Dengan Membuat Busur Panah Budget High Quality

\begin{abstract}
PVC Arrow Bow is an arrow bow which has several advantages compared to other arrow arc that is economical and the katahan is in use until 1000 hero is released from the bow.PVC pipe is a commonly used equipment to drain water from one place to another. PVC pipe has a good strength when compared withother pipes.PVC arrow bow is an arc bow made from PVC pipe. The process of arc making is done by a very is done at a relatively low temperature. The PVCn pipe is cut and adjusted to the desired size and then pressed the adges. This pressing is futher processed by using the pipe press tool using human power, the silenced for 25 minutes until the arc is formed, then the pipe that has been in the press and membentuk earlier in the paint by using oil paint according to the desired colour.the result of this painting is silenced until the paint dries and then carried by using nylon thread so that when the palm of the hand holding the bow is not slippery so that when pulling the hand arc strap is not seperated from the bow of the arrow. This PVC arrow bow has high economic value because it can be used for children, adolescent to adults so it does not have to buy an arrow bow whose price is much more expensive than the bow bow made from PVC pipe so that this $P V C$ arrow bow can be a business oportunity for local communities to improve their economies.
\end{abstract}

Keywords: Become a Millionaire By Making Law Budget Hight Arrow Quality Arrow

\section{PENDAhuluan}

Kecamatan Juluk Aceh Timur khusus desa/Gampong Juluk merupakan desa yang banyak menggunakan pipa PVC sebagai alat bantu untuk mengalirkan air buat kebutuhan sehari hari. Desa tersebut hampir disetiap rumah penduduk menggunakan pipa PVC dalam jumlah yang besar. Selama ini pipa PVC yang mereka ketahui hanya dapat digunakan sebagai alat untuk mengalirkan air dari satu tempat ke tempat yang lain di kecamatan tersebut. Masyarakat di desa tersebut tidak pernah mengolah pipa PVC menjadi alat yang dapat digunakan sebagai alat olahraga seperti busur panah. Dari hasil wawancara dengan masyarakat setempat mereka tidak mengetahui cara pembuatan pipa PVC menjadi busur panah, yang mereka ketahui adalah menggunakan pipa PVC sebagai alat untuk 
mengalirkan air dari mata air ke kamar mandi penduduk untuk dijadikan air mandi dan kegiatan rumah tangga lainnya. selain itu mereka juga membuang sisa pipa PVC sisa dari pengaliran air dari mata air ke kamar mandi, sementara pipa PVC ini dapat dimanfaatkan baik anak2, remaja dan dewasa untuk belajar memanah seperti Rasulullah pernah berpesan kepada sahabat “ Ajari Anakmu Berenang, Memanah dan Berkuda ". Dari pengolahan pipa PVC tersebut juga menghasilkan busur panah yang dapat dipakai sebagai alat olahraga dan dapat juga di jual belikan kepada masyarakat yang senang dengan olahraga memanah dan pada saat sekarang ini di setiap sekolah islam terpadu mengembangkan ektrakulikuler memanah di sekolah sebagai salah satu cabang olahraga yang di kembangkan di sekolah.

Panah Adalah Senjata yang panjang dan kecil seperti tombak, tajam pada ujungnya dan diberi bulu pada pangkalnya yang dilepaskan dengan busur, sedangkan memanah adalah melepaskan anak panah pada target atau sasaran (W.J.S. Poerwadarminto, 1996:700). Olahraga panahan termasuk cabang olahraga yang bergabung dalam PRIMA, seringkali dianggap sebagai olahraga yang sederhana dan tidak sulit (Soegiyanto, 2011:28). Seharusnya panahan yang merupakan budaya bangsa dapat dikembangkan dalam bentuk olahraga bergengsi, bermutu dan menarik di mata masyarakat. Sejalan dengan itu menurut Prasetyo (2010:66) olahraga panahan bukan olahraga sembarangan tetapi merupakan suatu bentuk seni meditasi, karena bagi pemanah yang unggul, pemanah dan sasaran bukan merupakan lawan, tapi telah lebur jadi satu.

Panahan menurut Seidel, at al (1975: 90) dalam Munawar, at al $2014: 4$ ) adalah suatu aktivitas yang memerlukan tenaga yang memadai untuk di transfer dari busur ke panah supaya menngerakkan anak panah ke sasaran yang dituju. Selain itu panahan menurut Tursi \& Napolitano, (2014: 571) adalah olahraga keterampilan yang ditandai dengan pengulangan yang setepat mungkin. Mann \& Littke, 1989 (dalam Ertan et al, 2005 : 95 ) menyatakan bahwa memanah dapat digambarkan sebagi olahraga yang relatif statis membutuhkan kekuatan dan daya tahan tubuh bagian atas, khusunya bahu dan lengan. Olahraga panahan adalah orahraga yang membutuhkan skill khusus, baik ketepatan, koordinasi maupun melatih mental dan meningkatkan jasmani secara prima. Hal ini sejalan dengan pendapat Loreyer et al (1993) yang menyatakan bahwa keterampilan dalam memanah didefinisikan sebagai kemampuan untuk menembak panah ke target yang diberikan dalam rentang waktu dan akurasi tertentu, sejalan dengan itu, menurut Nishizone et al, (1987 : 364), untuk mendapatkan rekor yang baik dalam kompetensi memanah diperlukan keseimbangan yang baik dan kemampuan menembak selama proses panahan. Terdapat 6 tahap gerakan dalam teknik memanah (Nishizone et al, 1987) yaitu persiapan memanah, menarik tali busur, full draw, membidik, melepaskan tali dan gerak lanjut, sedangkan Pekalski (1990) membedakan teknik memanah dri interaksi antara busur panah dan pemanah.

\section{HASIL DAN DISKUSI PENGABDIAN}

Kegiatan PKM ini akan dilaksanakan dalam tiga tahapan yang terdiri atas: (1) pelatihan tentang pembuatan busur panah dari piva PVC dan sosialisasi Olahraga Memanah, (2) pembagian busur panah kepada anak - anak sekolah dasar dan menengah ,(3) monitoring perkembangan olahraga memanah serta evaluasi pelaksanaan kegiatan melalui kuesioner. Kegiatan yang telah dilaksanakan meliputi kegiatan tahap satu dan dua.

\section{Pelatihan Pembuatan Busur Panah Dari Piva PVC} Kegiatan pelatihan pembuatan busur panah dan sosialisasi olahraga memanah dipusatkan di mushola Desa Blang Uyok Kecamatan Julok Aceh Timur. Jumlah peserta yang hadir dalam kegiatan tahapan pertama ini sebanyak 6 orang. Diharapkan pemuda pemuda yang hadir dalam kegiatan dapat mengajarkannya kepada masyarakat lainnya yang belum terjangkau. Pada kegiatan pelatihan pembuatan busur panah ini dijelaskan berbagai cara yang dapat dilakukan masyarakat untuk membuat busur panah. Dari kegiatan tanya jawab, masyarakat mengeluhkan kurangnya pelatihan - pelatihan seperti ini yang dilakukan pemerintah kepada pemuda - pemuda setempat di Kecamatan Julok Aceh Timur. Oleh karena itu tim pelaksana melatihkan para pemuda yang ada di gampong julok bagaimana cara membuat busur panah dari piva PVC.

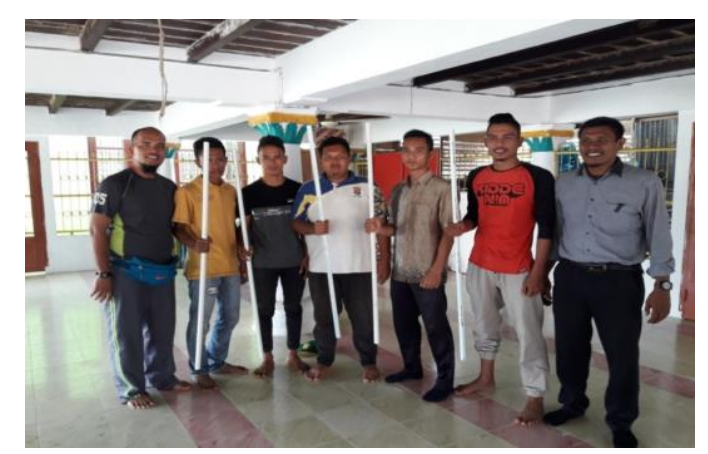

Gambar 1. Peserta Kegiatan Pelatihan Pembuatan Busur Panah

Pada kegiatan pembuatan busur panah diperkenalkan beberapa jenis busur panah yang dapat di buat dari piva PVC. Sejumlah sampel piva PVC ini diperkenalkan langsung kepada masyarakat agar masyarakat lebih mudah membuatnya. Piva PVC yang diperkenalkan antara lain Wavin $1 / 2$ inchi, Wavin $3 / 4$ inchi dan Piva Rucika, Sebagai alat pelengkap juga digunakan piva biasa. Masyarakat yang umumnya merupakan pemuda sangat terkesan dengan kegiatan merubah piva PVC yang biasa digunakan untuk mengalirkan air dari rumah ke rumah ini di jadikan busur panah untuk olahraga memenah. Masyarakat juga baru mengetahui bahwa bahwa piva PVC yang selama ini ada disekitar mereka sebagai alat untuk 
mengalirkan air dari mata air setempat ke rumah rumah penduduk merupakan benda yang dapat di buat alat olahraga yaitu busur panah.

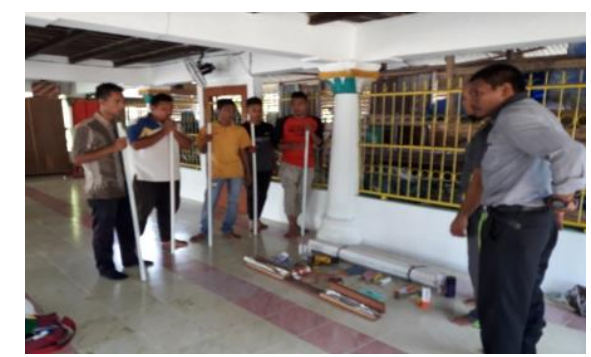

Gambar 2. Kegiatan Sosialisasi Pembuatan Busur Panah

\section{Pembagian Busur Panah}

Kegiatan pembagian busur panah dan pelatihan olahraga memanah dipusatkan di mushola Desa Blang Uyok Kecamatan Julok Aceh Timur. Jumlah peserta yang hadir dalam kegiatan tahapan kedua ini sebanyak 6 orang. Beberapa jenis pipa PVC yang dibagikan kepada masyarakat antara lain wavin $1 / 2$, wavin $3 / 4$ dan Rucika.

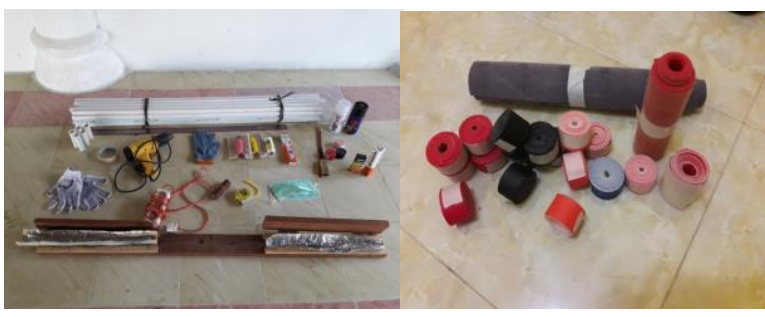

Gambar 3. Beberapa Alat Yang Digunakan Pembuatan Busur Panah

Setelah piva dibagikan maka dilakukan kegiatan pelatihan cara membuat busur panah dari piva tersebut yang meliputi praktek pembuatan busur panah, memotong piva, mengukur piva, cara membengkokkan piva, teknik meluruskan busur, dan praktek menghaluskan piva dengan amplas, mengecat atau mewarnai piva dengan cat semprot, dan pembuatan string untuk tempat meletakkan hero atau anak panah. Tim pelaksana mencontohkan dan mengarahkan peserta kegiatan untuk mempraktekkan sendiri membuat busur panah dari piva PVC. Peserta memberikan respon yang sangat positif yang terlihat dari partisipasi aktif semua peserta mencoba langsung membuat busur dari Piva PVC.

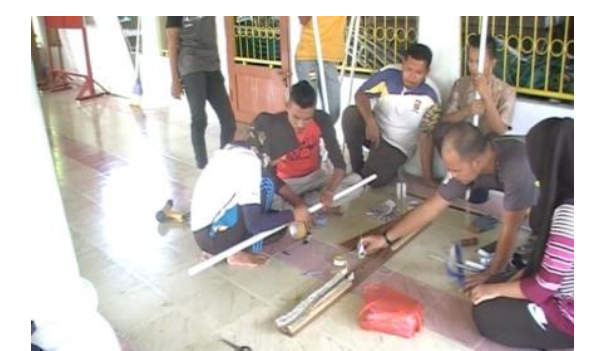

Gambar 4. Praktek Pembuatan Busur Panah

\section{KESIMPULAN}

Berdasarkan kegiatan yang telah dilakukan, maka dapat disimpulkan bahwa pemahaman awal masyarakat mengenai beberapa jenis pipa PVC yang dapat digunakan untuk pembuatan busur panah masih terbatas. Namun, masyarakat sangat antusias untuk mengenal secara langsung jenis-jenis piva PVC yang dapat dibuat busur dan mempraktikkan cara membuat busur panah. Masyarakat termotivasi untuk berpartisipasi aktif membuat busur panah dengan menggunakan piva PVC.

\section{UCAPAN TERIMAKASIH}

Penghargaan kami berikan dengan tidak lupa mengucapkan terimakasih kepada Rektor Universitas Samudra dan Lembaga Penelitian dan Pengabdian Masyarakat Universitas Samudra berdasarkan No.118/UN54/2017 dapat menyelesaikan program pengabdian masyarakat ini. Ucapan terimakasih juga diberikan kepada perangkat blang uyok aceh timur dan masyarakat blang uyok yang banyak membantu proses pengumpulan informasi priode juni - agustus 2017 di gampong blang uyok kecamatan julok Aceh Timur dan mahasiswa program studi pendididkan yang ikut serta dalam mensukseskan kegiatan pengabdian masyarakat ini.

\section{DAFTAR PUSTAKA}

Ertan , H, Kentel, B (2005), Reliability and Validity Of An Archery Chronometer, Journal of Sport an Medicine 4 . ( $95-104)$.

Nishizone, A, Shibayama, H, Izuta, T \& Saito, K. (1987), Analysis Of Archery Shooting Technique by Means of EMG. Internasional Society Of Biomechanics in Sport Proceedings, Symposium V. Athens, Greece.

Pekalskii, R, (1990), Experimental and Theoretical Research in Archery. Journal of Sport Sciences $8,259-279$.

Prasetyo Yudik. (2011), Olahraga Panahan. Yogyakarta : FIK UNY

Soegyanto, (2011), Kondisi Atlet Panahan Program Atlet Andalan Nasional Indonesia Emas (Prima). Jurnal Media Ilmu Keolahragaan Indonesia. Dipublikasi Juli 2011. ISSN:20886820.

W.J.S. Poerwadarminto. ( 1996 ). Kamus Umum Bahasa Indonesia. Jakarta: Balai Pustaka. 